\title{
E-Waste Generation and Management Practices in Dehradun, India
}

\author{
Anupriya Sharma Ghai, Kapil Ghai, Divya Kapil, Neetu Sharma
}

\begin{abstract}
The advancement in the electrical and electronic equipment and change in technology increases the demand of electronics appliances in the developing countries. People purchase electronic goods due to new features and capabilities. A lot more people sold or discard the older equipment's without the knowledge of useful life which leads to enormous used electronic equipment called electronic waste (E-waste). In the developing countries like India which ranked fifth in producing $e$-waste globally, due to the lack of enough infrastructure and improper management practice. The present study evaluates the knowledge, management, dispose practices of e-waste and hazardous substances generated by the citizens of Dehradun, India in year 2019. An online questionnaire on 300 respondents based on calculating the sample size requirement was done in mid of year 2019.The outcome of the study show case the effect of e-waste generated by different income base groups with the inventory used by citizens in one year. Total number of heavy metals and plastics generated by household appliances and ICT and consumer electronics were also measured. The result showed up the need of awareness and urgent requirement of the serious issues of E-waste. The state government must involve without waiting for the upcoming adverse effects on environment and health risks to human lives.
\end{abstract}

Keywords-E-waste, inventory assessment, heavy metals, income based category, electrical and electronic equipment

\section{INTRODUCTION}

The exponential growth in electronic industry results the increase in demand in the last two decades. People start buying more electronic devices which include mobile phones, laptops, households' appliances and other electronic equipment. The developing countries users depends on developed countries for electronic equipment's, In India a substantial portion of users primarily depends on Europe and North America for electronic devices [1].The term "digital gap" in developing countries increases the transboundary passage of second-hand devices. As per the report by the International Data Corporation India's market of repaired and second hand phones grew by 14\% from 2018 . India's feature phone market of the second-hand set increased up to 32.3 million units shipped in the first quarter of 2019 [2].India attracts both the second-hand market as well as phone markets of features in which millions of people buy smartphones, tablets every year. Many of the consumers switch for the new features and many can't afford it.

Revised Manuscript Received on September 25, 2019.

Anupriya Sharma Ghai (Corresponding Author), Department of Computer Applications, Graphic Era Hill University, Dehradun, India. Email: anupriya@gehu.ac.in

Kapil Ghai, Department of Chemistry, Graphic Era Hill University, Dehradun, India.

Divya Kapila, Department of Computer Applications, Graphic Era Hill University, Dehradun, India.

Neetu Sharma, Department of Chemistry, Graphic Era University, Dehradun, India.
There is an online sale marketplace in India for second-hand electronics which includes mobile phones, laptopsand gaming consoles which is again a million-dollar industry and has investors from China and other parts of the world [3].People don't even knowabout the useful life of consumer electronic products which is relatively short and secondhand equipment leads to obsolete the electronic device. This creates anenormous waste of outdated and rejected electronic equipment which termed as 'E-waste'. Electronic waste or E-waste can be defined as electrical and electronic equipment such as household electronics, mobile phones, computers, laptops, LCD, refrigerator and other old, outdated or obsolete electronic which have been disposed in improper way by their original users [4].E-waste is known to be the fastest-growing waste across the globe. Due to its harmfulconsequence on the environment, it is categorized under pollutants. As per UN University (UNU), the world disposes of approximately $50 \mathrm{MT}$ (Million Tons) of e-waste which includes discarded equipment such as television sets, refrigerators, laptops, phones, and other electronic wastes.These discarded wastes contain hazardous constituents that can lead to environmental and health risks if they are improperly disposed of [5].The management and dispose of hazardous constituents are as important as other solid waste management. The developing countries are facing challenges with the internally as well as imported illegally used electronic goods. In these countries, due to the lack of enough infrastructure for handling the E-waste, they sometimes buried, burnt, or dumped these devices. Recycling, material recovery is negligible or highly polluting sometimes costly. As per the report shown by Global E-Waste Monitor in 2017, India generated about 2 MTof E-waste per year, which makes its position in the top five highest-producing e-waste across the globe, after the US, China, Japan, and Germany[6].As per the ASSOCHAM, said that it would reach 5.2 MT by 2020[7].

Our study represents the evaluation of e-waste generation and current management practices in Dehradun, India. The E-waste management practicesinclude the amount of Ewaste generated from householdsandincrease the awareness of its collection and safe disposal.

\section{STUDY AREA}

The rapid increase in the education sector and Information Technology (IT) industries in megacities of India. Dehradun is known as theeducation hub of North India. Dehradun is the capital of Uttarakhand, near the Himalayan foothillsthe 28th state of India. The city has an area of 3,088 sq.km, with population of 16, 96, 694 (Census of India, 2011).

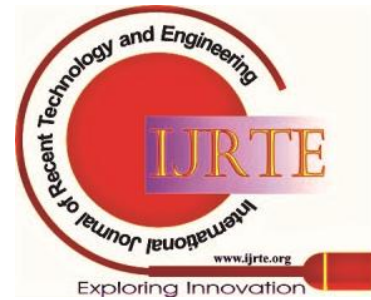




\section{E-Waste Generation and Management Practices in Dehradun, India}

The IT industries, educational institutes are in the surroundings of Dehradun. The state has 13 districts and has only seven registered E-waste dismantlers and recyclers in which few seem to expire in 2018.As per the official website of the state's pollution control board, there is no dedicated database available after 2017. The state's generated 3671 MT of hardware and 9860 MT of quantity send to recyclers which contains hazardous substances [8].

\section{MATERIALS AND METHODS}

To see the knowledge of E-waste among the citizens of Dehradun an online survey was conducted in the mid of the year 2019.The main objective of the study was to gather information about (1) Socio-economic status of the respondents and households (2) E-waste responsivenessand education practices implemented by 300 respondents of Dehradun (3) EEE consumption by income groups and generated e-waste (4) E-waste generated by Dehradun (5) Hazardous substances generated by E-waste. The respondents are classified based on Kuppuswamy Socioeconomic Status Scale [9].

\subsection{Sample size}

\section{RESULTS AND DISCUSSION}

\subsection{Analysis of Socio-economic profile}

Table 1: Socio-economic profile of households in Dehradun

\begin{tabular}{|c|c|c|}
\hline Variable & Occurrence & Percentage \\
\hline Gender & & \\
Male & 124 & $41.30 \%$ \\
Female & 176 & $58.70 \%$ \\
\hline Age Groups (y) & & \\
$18-25$ & 83 & $27.60 \%$ \\
25-60 & 142 & $47.30 \%$ \\
$>60$ & 75 & $25 \%$ \\
\hline Income Groups & & \\
LIG & 167 & $55.60 \%$ \\
MIG & 88 & $29.30 \%$ \\
HIG & 45 & $15 \%$ \\
\hline Literacy & & $14.70 \%$ \\
Illiterate & 44 & $35.30 \%$ \\
<10th & 106 & $31 \%$ \\
Graduation & 93 & $19 \%$ \\
Post-Graduation & 57 & $30.30 \%$ \\
\hline Job Nature & & $16.60 \%$ \\
Student & 91 & $8.90 \%$ \\
Professional & 50 & \\
Service man & 35 & \\
Housemaker & 70 & \\
Businessman & 30 & \\
others & 24 & \\
\hline
\end{tabular}

$$
\mathrm{n}=\mathrm{z}^{2} \mathrm{pq} / \mathrm{d}^{2}
$$

Where, $n$ is the required sample size take $\mathrm{p}=0.5$ in which we assume that only $50 \%$ of the population of households are aware of e-waste management and disposal) required $(\mathrm{d}=5.65 \%)$ By putting the above values in the above a sample size of approximate 300 generated that is exactly 301.The collective information of 300 households was analyzed to E-waste generation and disposal practices in

\subsection{Reliability of data}

To calculate the sample on finite population correction. The Dehradun city.

\section{eliability of thedata is calculated by Cronbach's-alpha which is 0.916 for the questionnaire. and in acceptable range \\ [10].}

value al 


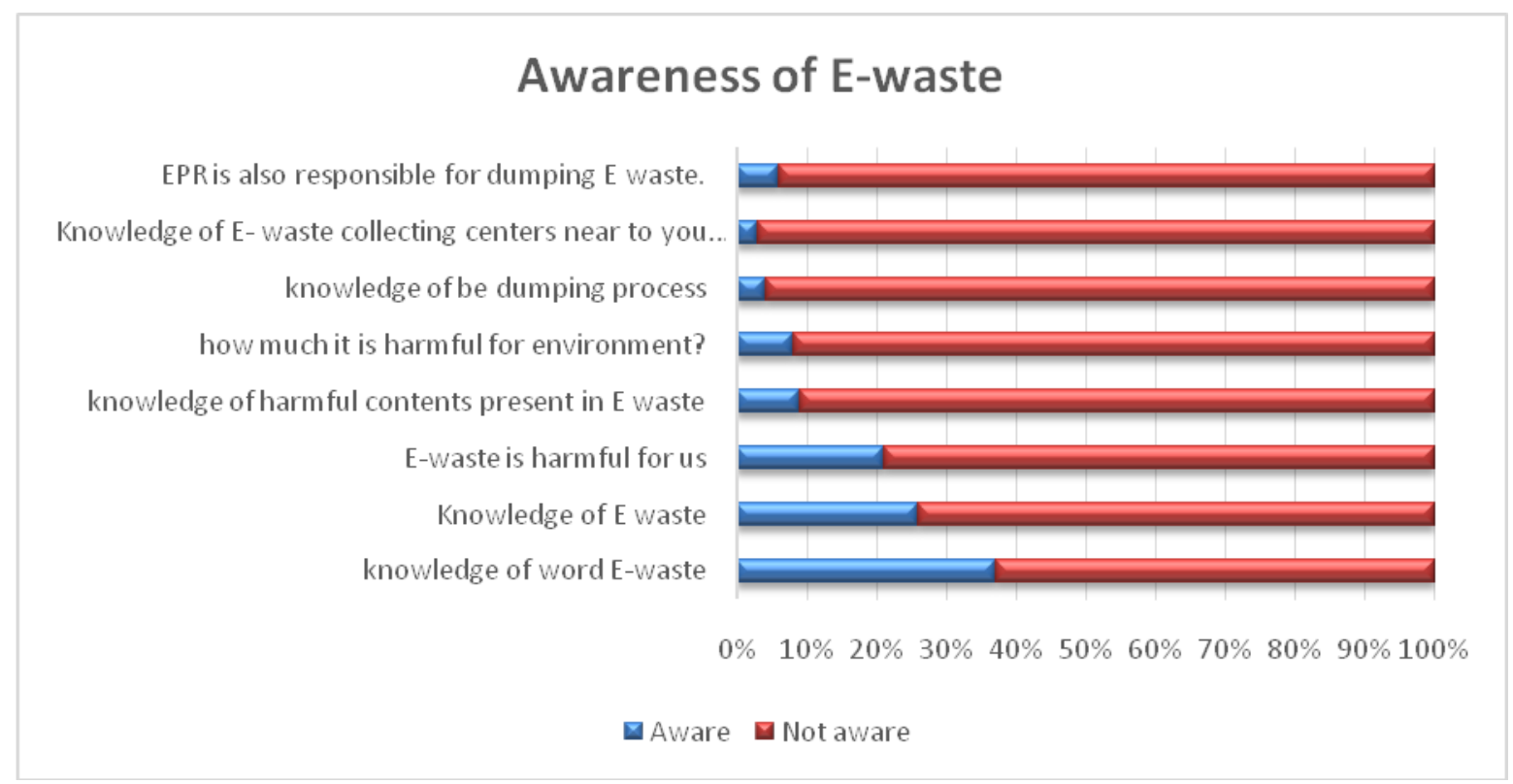

Figure 1: Public knowledge on E-waste awareness in Dehradun

Figure 1 represents the knowledge of respondents on Ewaste and found that only $26 \%$ of respondents have knowledge of E-waste, whereas only $9 \%$ of respondents had knowledge of its environmental hazards. A significant percentage of respondents that is $97 \%$ were found unaware about the E-waste management practices and guidelines outlined by the Government of India (CPCB, 2016).

\subsection{Inventory Evaluation}

The EEE were recorded through the study with respect to income groups in which LIG respondent have a smaller number of appliances as compared to other income groups. Figure 2 represents the inventory available to different income groups.

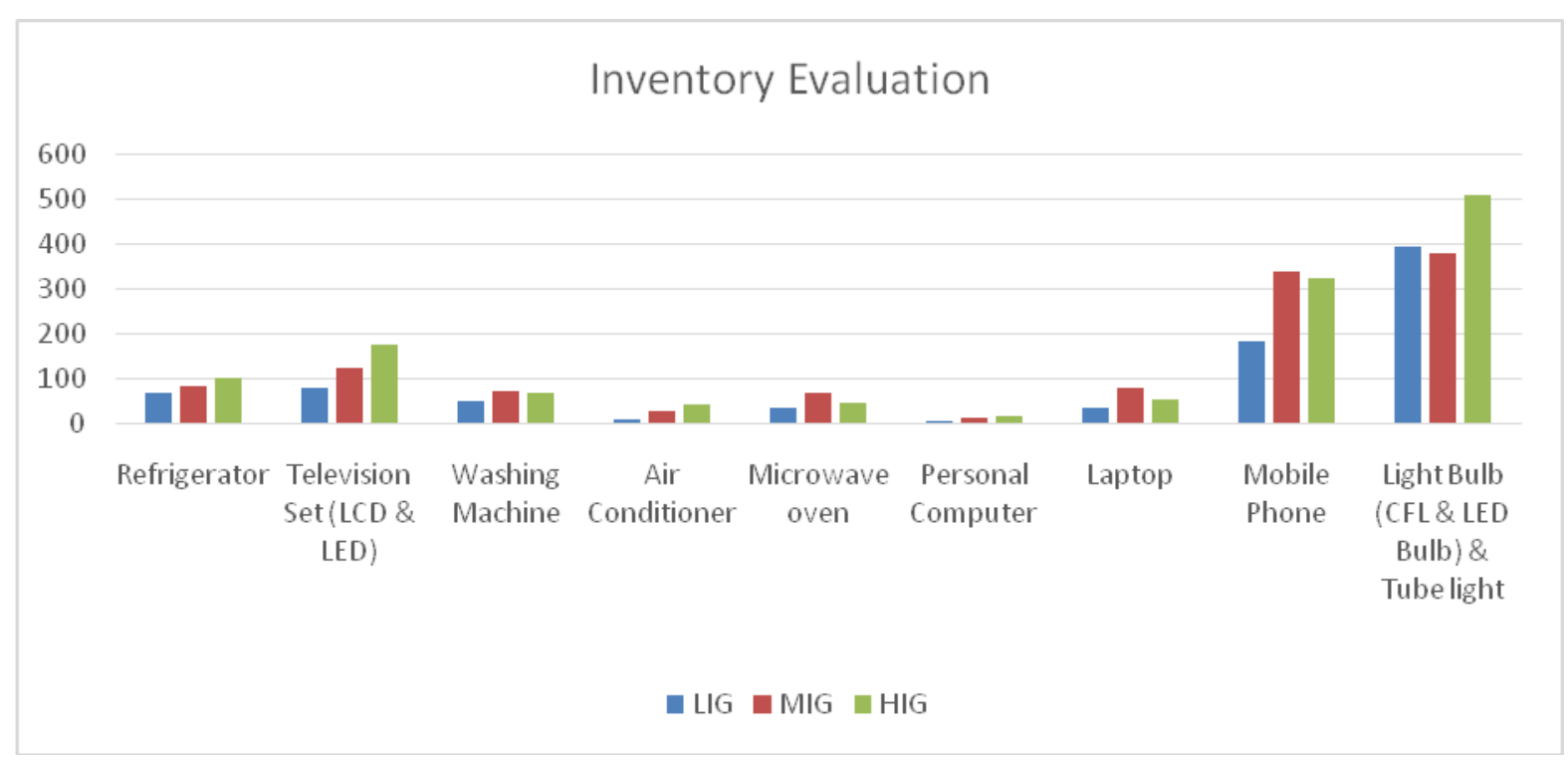

Figure 2 Available inventory in houses of different income groups.

On an average, each household had $\sim 0.9$ refrigerator, $\sim 1.3$ television (TV), $\sim 0.9$ washing machines $\sim 0.3$ air conditioners $(\mathrm{AC}), \sim 0.9$ microwave oven,$\sim 0.1$ personal computers and $\sim 0.9$ laptops, whereas $\sim 2.8$ mobile phones and 0.9Light Bulb (CFL \& LED Bulb) \& Tube light respectively.

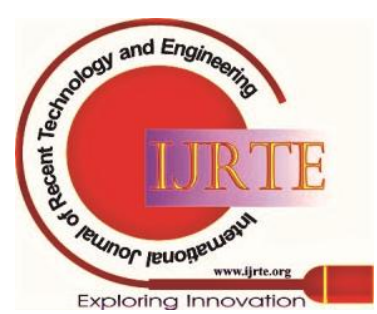




\section{E-Waste Generation and Management Practices in Dehradun, India}

\section{EEE Dispose method}

Light Bulb (CFL \& LED Bulb) and Tubelight

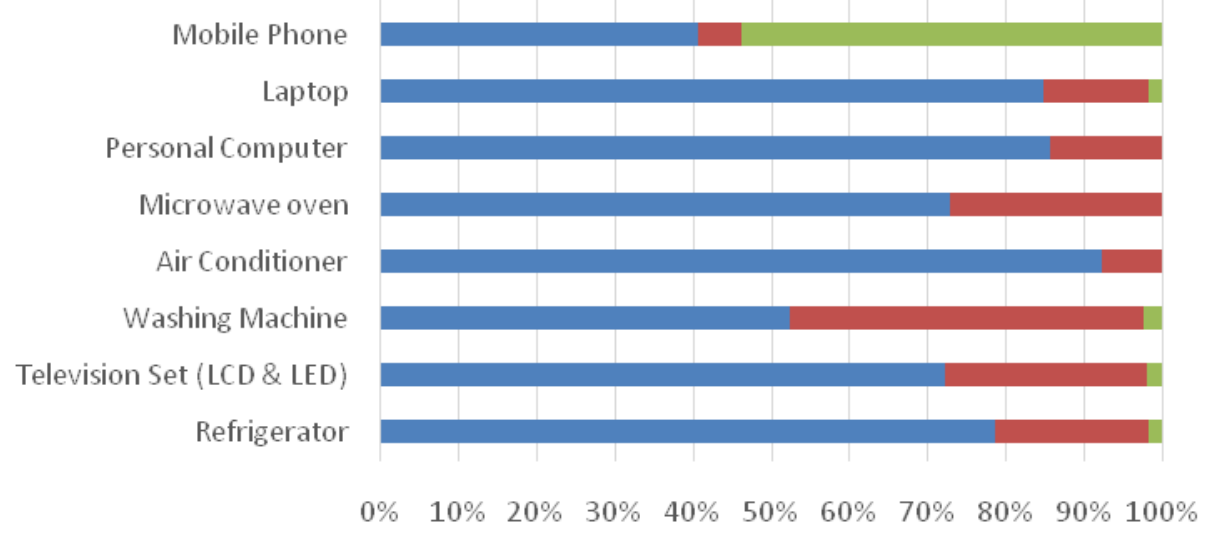

- Sell to Second-hand Consumer/dealer

- Sell to scrap dealer

- Dispose of with house waste or put on street

Figure 3 EEE dispose method used by respondents

As per the evaluation in Figure 4 it clear that disposal methods used by respondents in Dehradun is secondhand consumers or dealers.

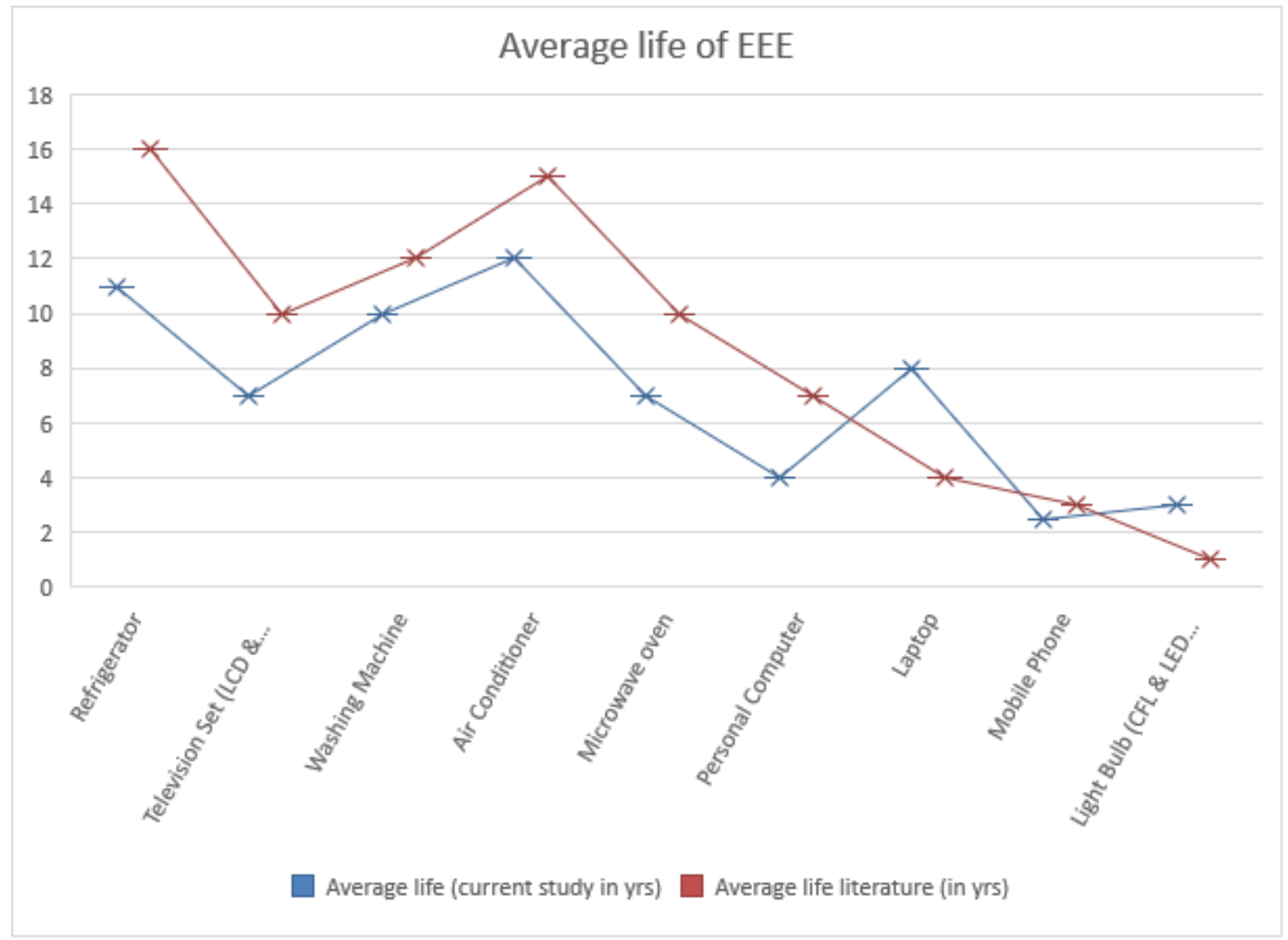

Figure 4 Average life of EEE (as per study) with average life of EEE(as per literature)

Figure 5 represents the comparison of the average life or End of life (EOL) of the appliances before the discard/ sold to second hand dealer or to throw in scrap based with the average life available according to the literature [11].
Published By:

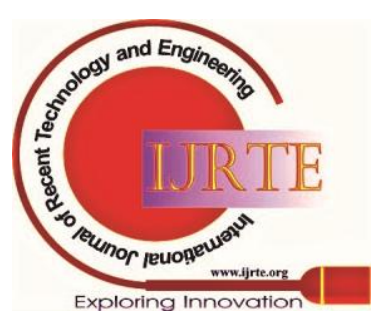


Table 2.Represents the estimated E-waste generated by Dehradun (approximated number of houses 3,47,001)

\begin{tabular}{|c|c|c|c|c|c|c|c|}
\hline S. No. & $\begin{array}{l}\text { Electronic } \\
\text { Appliances }\end{array}$ & 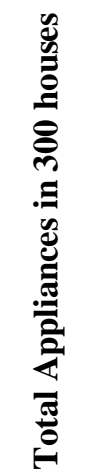 & 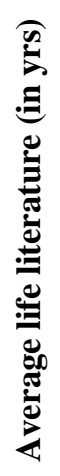 & 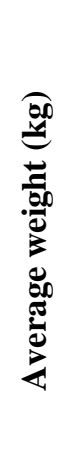 & $\begin{array}{l}\text { Approx. E- } \\
\text { waste } \\
\text { production } \\
\text { (kg/house/yrs) }\end{array}$ & $\begin{array}{c}\text { Approx. E-waste } \\
\text { production } \\
\text { (kg/yrs) in } 300 \\
\text { houses }\end{array}$ & $\begin{array}{c}\text { E-waste generation in } \\
\text { Dehradun (ton /yr) (No. } \\
\text { of households in Dehadun } \\
=\mathbf{3 , 4 7 , 0 0 1 )}\end{array}$ \\
\hline 1 & Refrigerator & 261 & 16 & 35 & 1.9 & 570.94 & 660.39 \\
\hline 2 & $\begin{array}{l}\text { Television Set } \\
\text { (LCD \& LED) }\end{array}$ & 386 & 10 & 7.5 & 0.97 & 289.5 & 334.86 \\
\hline 3 & Washing Machine & 196 & 12 & 68 & 3.7 & 1110.67 & 1284.67 \\
\hline 4 & Air Conditioner & 85 & 15 & 75 & 1.42 & 425 & 491.58 \\
\hline 5 & Microwave oven & 156 & 7 & 16 & 1.19 & 356.57 & 412.44 \\
\hline 6 & $\begin{array}{l}\text { Personal } \\
\text { Computer }\end{array}$ & 36 & 7 & 9.9 & 0.17 & 50.91 & 58.89 \\
\hline 7 & Laptop & 172 & 4 & 3.5 & 0.5 & 150.5 & 174.08 \\
\hline 8 & Mobile Phone & 854 & 3 & 0.1 & 0.09 & 28.47 & 32.93 \\
\hline 9 & $\begin{array}{c}\text { Light Bulb (CFL } \\
\text { \& LED Bulb) \& } \\
\text { Tube light }\end{array}$ & 1291 & 1 & 0.1 & 0.43 & 129.1 & 149.33 \\
\hline 10 & total & 3437 & & & 10.37 & 3111.66 & 3599.16 \\
\hline
\end{tabular}

Table 3 Represents the E-waste generated by different income groups

\begin{tabular}{|c|c|c|c|c|c|c|}
\hline $\begin{array}{l}\text { Income } \\
\text { group }\end{array}$ & $\begin{array}{l}\text { Electronic } \\
\text { Appliances }\end{array}$ & $\begin{array}{c}\text { Total } \\
\text { Appliances }\end{array}$ & $\begin{array}{l}\text { Average life } \\
\text { literature } \\
\text { (in yrs) }\end{array}$ & $\begin{array}{c}\text { Average } \\
\text { weight (kg) }\end{array}$ & $\begin{array}{l}\text { Approx. E- } \\
\text { waste } \\
\text { production } \\
\text { (kg/house/yrs) }\end{array}$ & $\begin{array}{c}\text { Approx. E-waste } \\
\text { production }(\mathrm{kg} / \mathrm{yrs}) \text { in } \\
\text { LIG houses }\end{array}$ \\
\hline \multirow{8}{*}{ LIG } & Refrigerator & 72 & 16 & 35 & 0.94 & 157.5 \\
\hline & $\begin{array}{c}\text { Television } \\
\text { Set (LCD \& } \\
\text { LED) }\end{array}$ & 81 & 10 & 7.5 & 0.36 & 60.75 \\
\hline & $\begin{array}{l}\text { Washing } \\
\text { Machine }\end{array}$ & 53 & 12 & 68 & 1.8 & 300.33 \\
\hline & $\begin{array}{c}\text { Air } \\
\text { Conditioner }\end{array}$ & 11 & 15 & 75 & 0.33 & 55 \\
\hline & $\begin{array}{c}\text { Microwave } \\
\text { oven }\end{array}$ & 38 & 7 & 16 & 0.52 & 86.86 \\
\hline & $\begin{array}{l}\text { Personal } \\
\text { Computer }\end{array}$ & 6 & 7 & 9.9 & 0.05 & 8.49 \\
\hline & Laptop & 37 & 4 & 3.5 & 0.19 & 32.38 \\
\hline & $\begin{array}{l}\text { Mobile } \\
\text { Phone }\end{array}$ & 185 & 3 & 0.1 & 0.04 & 6.17 \\
\hline
\end{tabular}


E-Waste Generation and Management Practices in Dehradun, India

\begin{tabular}{|c|c|c|c|c|c|c|}
\hline & $\begin{array}{c}\text { Light Bulb } \\
\text { (CFL \& } \\
\text { LED Bulb) } \\
\text { \& Tube } \\
\text { light }\end{array}$ & 397 & 1 & 0.1 & 0.24 & 39.7 \\
\hline & TOTAL & & & & 4.47 & 747.17 \\
\hline \multirow{10}{*}{ MIG } & Refrigerator & 86 & 16 & 35 & 2.14 & 188.13 \\
\hline & $\begin{array}{l}\text { Television } \\
\text { Set (LCD \& } \\
\text { LED) }\end{array}$ & 126 & 10 & 7.5 & 1.07 & 94.5 \\
\hline & $\begin{array}{l}\text { Washing } \\
\text { Machine }\end{array}$ & 74 & 12 & 68 & 4.77 & 419.33 \\
\hline & $\begin{array}{c}\text { Air } \\
\text { Conditioner }\end{array}$ & 28 & 15 & 75 & 1.59 & 140 \\
\hline & $\begin{array}{l}\text { Microwave } \\
\text { oven }\end{array}$ & 71 & 7 & 16 & 1.84 & 162.29 \\
\hline & $\begin{array}{l}\text { Personal } \\
\text { Computer }\end{array}$ & 13 & 7 & 9.9 & 0.21 & 18.39 \\
\hline & Laptop & 81 & 4 & 3.5 & 0.81 & 70.88 \\
\hline & $\begin{array}{l}\text { Mobile } \\
\text { Phone }\end{array}$ & 342 & 3 & 0.1 & 0.13 & 11.4 \\
\hline & $\begin{array}{c}\text { Light Bulb } \\
\text { (CFL \& } \\
\text { LED Bulb) } \\
\text { \& Tube } \\
\text { light }\end{array}$ & 382 & 1 & 0.1 & 0.43 & 38.2 \\
\hline & TOTAL & & & & 12.99 & 1143.1 \\
\hline \multirow{10}{*}{ HIG } & Refrigerator & 103 & 16 & 35 & 5.01 & 225.31 \\
\hline & $\begin{array}{l}\text { Television } \\
\text { Set (LCD \& } \\
\text { LED) }\end{array}$ & 179 & 10 & 7.5 & 2.98 & 134.25 \\
\hline & $\begin{array}{l}\text { Washing } \\
\text { Machine }\end{array}$ & 69 & 12 & 68 & 8.69 & 391 \\
\hline & $\begin{array}{c}\text { Air } \\
\text { Conditioner }\end{array}$ & 46 & 15 & 75 & 5.11 & 230 \\
\hline & $\begin{array}{c}\text { Microwave } \\
\text { oven }\end{array}$ & 47 & 7 & 16 & 2.39 & 107.43 \\
\hline & $\begin{array}{l}\text { Personal } \\
\text { Computer }\end{array}$ & 17 & 7 & 9.9 & 0.53 & 24.04 \\
\hline & Laptop & 54 & 4 & 3.5 & 1.05 & 47.25 \\
\hline & $\begin{array}{l}\text { Mobile } \\
\text { Phone }\end{array}$ & 327 & 3 & 0.1 & 0.24 & 10.9 \\
\hline & $\begin{array}{c}\text { Light Bulb } \\
\text { (CFL \& } \\
\text { LED Bulb) } \\
\text { \& Tube } \\
\text { light }\end{array}$ & 512 & 1 & 0.1 & 1.14 & 51.2 \\
\hline & TOTAL & & & & 27.14 & 1221.38 \\
\hline
\end{tabular}

Table 4. Represents the hazardous substances generated by Dehradun per year 
International Journal of Recent Technology and Engineering (IJRTE) ISSN: 2277-3878, Volume-8 Issue-2S12, September 2019

\begin{tabular}{|c|c|c|c|c|c|c|c|}
\hline Appliances & $\begin{array}{c}\text { Total } \\
\text { quantity } \\
\text { (MT) }\end{array}$ & $\begin{array}{c}\text { Ferrous } \\
\text { metal }\end{array}$ & Aluminium & Copper & Cadmium & Lead & Plastics \\
\hline $\begin{array}{c}\text { household } \\
\text { appliances }\end{array}$ & 2861 & 1272 & 477 & 423 & 4 & 48 & 637 \\
\hline $\begin{array}{c}\text { ICT and } \\
\text { consumer } \\
\text { electronics }\end{array}$ & 221.38 & 172 & 27 & 21 & 0.084 & 1.3 & 0.0017 \\
\hline Lamps/bulbs & 20.76 & - & 20.5 & 0.26 & - & - & - \\
\hline Total & 3103.14 & 1444 & 524.5 & 444.26 & 4.084 & 49.3 & 637.0017 \\
\hline
\end{tabular}

According to the table 4It can be observed that house hold appliances majorly generates the E-waste as compared to ICT and consumer electronics which contain only ferrous metal and small amounts of aluminum and copper.

\section{CONCLUSION}

The study evaluated the E-waste generation and lack of knowledge among the citizensof Dehradun. The unorganized sector and improper dispose generate 3599.16 MTof E-waste in year 2019.As per the pollution control board of Uttarakhanddatabase of 2017 , 9860 MT of quantity send to recyclers which contains hazardous substances in 2017.If we compared these two data values than it is concluded that values are increased in 2019. A need awareness among the citizens of Dehradun is must,which includes knowledge of E-waste, adverseeffects on environment as well as on human health due to hazardous substances present in EEE. This can be achieved all throughsessions to locals, advertisements through posters and banners and campaigns on available guidelines on Ewaste. The state government must organize the workshops on recycle and reuse.

\section{REFERENCES}

1. Nnorom, I. C., \&Osibanjo, O. (2008). Electronic waste (e-waste): Material flows and management practices in Nigeria. Waste Management, 28(8), 1472-1479.

2. Qu, Y., Wang, W., Liu, Y., \& Zhu, Q. (2019). Understanding residents' preferences for e-waste collection in China-A case study of waste mobile phones. Journal of Cleaner Production, 228, 52-62.

3. Bhasker, B. (2013). Electronic commerce: framework, technologies and applications. Tata McGraw-Hill Education.

4. Bhuie, A. K., Ogunseitan, O. A., Saphores, J. D., \& Shapiro, A. A. (2004, May). Environmental and economic trade-offs in consumer electronic products recycling: a case study of cell phones and computers. In IEEE International Symposium on Electronics and the Environment, 2004. Conference Record. 2004 (pp. 74-79). IEEE.

5. Misra, V., \& Pandey, S. D. (2005). Hazardous waste, impact on health and environment for development of better waste management strategies in future in India. Environment international, 31(3), 417431 .

6. Baldé, C. P., Forti, V., Gray, V., Kuehr, R., \& Stegmann, P. (2017). The Global E-waste Monitor-2017, United Nations University (UNU), International Telecommunication Union (ITU) \& International Solid Waste Association (ISWA), Bonn/Geneva/Vienna. ISBN Electronic Version, 978-92.

7. Kumar, A., Holuszko, M., \& Espinosa, D. C. R. (2017). E-waste: an overview on generation, collection, legislation and recycling practices. Resources, Conservation and Recycling, 122, 32-42.

8. Sahu, G. (2013). Environmental Regulatory Authorities in India: An Assessment of State Pollution Control Boards. Centre for Science, Technology \& Society School of Habitat Studies.
9. Kuppuswamy, B. (1981). Manual of socioeconomic status (urban)[M] New Delhi: Manasayan, 28.

10. Nunnally, J.C. (1978). Psychometric Theory. New York: McGrawHill.

11. Appliance., 2016. 23rd Annual Portrait of the U.S. appliance industry. Saturation, share-of market, and life expectancy figures are given along with a comprehensive listing of Who's Who in the Appliance Industry. Dana Chase Publication. 57, 83-110. 